\title{
Using Lead Isotopes and Trace Element Records from Two Contrasting Lake Tanganyika Sediment Cores to Assess Watershed - Lake Exchange
}

\author{
Kingsley O. Odigie ${ }^{a^{*}}$, Andrew S. Cohen ${ }^{b}$, Peter W. Swarzenski ${ }^{c}$, and A. Russell Flegal ${ }^{a}$ \\ ${ }^{a}$ WIGS Laboratory, Environmental Toxicology, University of California at Santa Cruz, CA 95064, \\ USA \\ ${ }^{b}$ Department of Geosciences, University of Arizona, 1040 E $4^{\text {th }}$ Street, Tucson, AZ 85721, USA \\ 'United States Geological Survey, 400 Natural Bridges Drive, Santa Cruz, CA 95060, USA \\ *Corresponding author: Kingsley O. Odigie \\ WIGS Laboratory \\ Environmental Toxicology \\ University of California at Santa Cruz \\ 1156 High Street, Santa Cruz, CA 95064 \\ Phone: (831) 459-5336 \\ Fax: (831) 459-3524 \\ E-mail: kodigie@ucsc.edu
}




\section{ABSTRACT}

Lead isotopic and trace element records of two contrasting sediment cores were examined to reconstruct historic, industrial contaminant inputs to Lake Tanganyika, Africa. Observed fluxes of $\mathrm{Co}, \mathrm{Cu}, \mathrm{Mn}, \mathrm{Ni}, \mathrm{Pb}$, and $\mathrm{Zn}$ in age-dated sediments collected from the lake varied both spatially and temporally over the past two to four centuries. The fluxes of trace elements were lower (up to 10-fold) at a mid-lake site (MC1) than at a nearshore site (LT-98-58), which is directly downstream from the Kahama and Nyasanga River watersheds and adjacent to the relatively pristine Gombe Stream National Park. Trace element fluxes at that nearshore site did not measurably change over the last two centuries (1815 to 1998), while the distal, mid-lake site exhibited substantial changes in the fluxes of trace elements - likely caused by changes in land use - over that period. For example, the flux of Pb increased by 300\% from 1871 to 1991. That apparent accelerated weathering and detrital mobilization of lithogenic trace elements was further evidenced by (i) positive correlations $(r=0.77$ to $0.99, p<0.05)$ between the fluxes of $\mathrm{Co}, \mathrm{Cu}, \mathrm{Mn}, \mathrm{Ni}, \mathrm{Pb}$, and $\mathrm{Zn}$ and those of iron (Fe) at both sites, (ii) positive correlations ( $\mathrm{r}=$ 0.82 to $0.98, \mathrm{p}<0.01, \mathrm{n}=9$ ) between the fluxes of elements ( $\mathrm{Al}, \mathrm{Co}, \mathrm{Cu}, \mathrm{Fe}, \mathrm{Mn}, \mathrm{Ni}, \mathrm{Pb}$, and $\mathrm{Zn}$ ) and the mass accumulation rates at the offshore site, (iii) the low enrichment factors $(E F<5)$ of those trace elements, and (iv) the temporal consistencies of the isotopic composition of $\mathrm{Pb}$ in the sediment. These measurements indicate that accelerated weathering, rather than industrialization, accounts for most of the increases in trace element fluxes to Lake Tanganyika in spite of the development of mining and smelting operations within the lake's watershed over the past century. The data also indicate that the mid-lake site is a much more sensitive and useful recorder of environmental changes than the nearshore site. Furthermore, the lead 
isotopic compositions of sediment at the sites differed spatially, indicating that the $\mathrm{Pb}$ (and other trace elements by association) originated from different natural sources at the two locations.

\section{INTRODUCTION}

\subsection{Trace Element Contamination in Central Africa}

It has been well documented that all kinds of human activities have markedly impacted the cycling and fate of many trace elements in the environment (Warren, 1981; Sañudo-Wilhelmy and Flegal, 1994; Nriagu, 1996; Soto-Jimenez et al., 2006). For example, 75\% of global atmospheric $\mathrm{Pb}$ contamination during the latter half of the $20^{\text {th }}$ century has been attributed to anthropogenic emissions, primarily from the combustion of leaded gasoline (Nriagu and Pacyna, 1988; Dunlap et al., 2008). These global perturbations have also been documented in Africa (Nriagu, 1992; Ettler et al., 2011), as evidenced in recent studies by Yang et al. (2010) and Conaway et al. (2012) that associated increased Hg fluxes to equatorial African lakes with increased atmospheric emissions of $\mathrm{Hg}$ from fossil fuel combustion over the past two centuries. However, such studies are few in number, and more information is still needed to adequately characterize the impacts of anthropogenic activities in Central Africa.

In addition to industrial emissions from fossil fuel combustion, other anthropogenic activities, including mining and smelting operations, have resulted in elevated trace element deposition in some parts of Africa on both local and regional scales (Banza et al., 2009; Nakayama et al., 2011). Unfortunately, these activities are particularly deleterious in developing countries, where environmental regulations are sometimes inadequate and/or 
poorly enforced. For example, highly elevated concentrations of labile $\mathrm{Cu}, \mathrm{Pb}$, and $\mathrm{Zn}$ were measured in sediment collected close to the Kabwe Mine in Zambia, which was recently ranked as one of the most polluted sites in the world (Tembo et al., 2006; Blacksmith Institute, 2007). Very high levels of Co $\left(610 \mathrm{mg} \mathrm{kg}^{-1}\right), \mathrm{Cu}\left(27,000 \mathrm{mg} \mathrm{kg}^{-1}\right), \mathrm{Pb}\left(480 \mathrm{mg} \mathrm{kg}^{-1}\right)$, and Zn $\left(450 \mathrm{mg} \mathrm{kg}^{-1}\right)$ were also measured in the topsoil near the Nkana copper smelter in the Copperbelt Province of Kitwe in Zambia, which were attributed predominantly to contamination from those mining and smelting operations (Ettler et al., 2011). Similarly, elevated levels of trace elements released from mining and smelting activities have been documented in other countries in the region, including the Democratic Republic of the Congo (Banza et al., 2009) and Tanzania (Marwa et al., 2012). Furthermore, environmental degradation has been exacerbated around Lake Tanganyika by the unregulated discharge of untreated industrial waste within its basin (West, 2001).

In addition to these industrial activities, many other anthropogenic perturbations - including widespread deforestation, agricultural development, and rapid urbanization - may contribute to elevated trace element releases into the environment via accelerated weathering and erosion. For example, deforestation (rates of up to $100 \%$ have been reported in some parts of the lake's watershed) and land-use conversions, which are a major threat to the lake, have been shown to increase soil erosion rates by up to 100-fold in Burundi (Bizimana and Duchafour, 1991; Cohen et al., 1993; Wells et al., 1999; Cohen et al., 2005a; O'Reilly et al., 2005). Elsewhere, studies (e.g., Quinton and Catt, 2007) have shown associations between land-use (e.g., agriculture) linked erosion and accelerated mobilization of trace elements. Moreover, it has been predicted that climate change-induced weathering and erosion rates will 
increase in much of the world, including Africa, which will exacerbate trace element fluxes (Yang et al., 2003; IPCC, 2013).

Consequently, projected trends in accelerated trace element releases and associated ecological impacts across much of Africa, including countries that border Lake Tanganyika pose substantial risk to human and environmental health (Banza et al., 2009; Marwa et al., 2012). These concerns have already been substantiated by measurements of blood $\mathrm{Pb}(\mathrm{BPb})$ levels in children in Kabwe, Zambia (Blacksmith Institute, 2007). On average, their BPb levels were $\sim 10-20$ times the current US level of concern $\left(5 \mu \mathrm{g} \mathrm{dL}^{-1}\right)(\mathrm{CDC}, 2012)$. Similarly, elevated levels of trace elements have been measured in cattle (e.g., up to $400 \mathrm{mg} \mathrm{kg}^{-}$

${ }^{1}$ of $\mathrm{Cu}$ and $250 \mathrm{mg} \mathrm{kg}^{-1}$ of $\mathrm{Zn}$ in dry tissue) in Kabwe, Zambia (Yabe et al., 2011).

\subsection{Environmental Changes in Lake Tanganyika}

In addition to the previously noted developmental changes that are occurring in Africa today, air and water temperatures at Lake Tanganyika have been increasing. For example, average annual air temperatures around the lake have increased by 0.5 to $0.7^{\circ} \mathrm{C}$ since the late 1970s (O'Reilly et al., 2003), and the temperature of the lower metalimnion ( 110 mdepth water column) of the lake has increased by $0.9^{\circ} \mathrm{C}$ between 1913 and 2000 (Tierney et al., 2010). Moreover, it has been predicted that surface temperatures in central Africa could rise by 1.25 to $1.5^{\circ} \mathrm{C}$ by the end of this century (IPCC, 2013). Wildfires and soil erosion, which mobilize trace elements and enhance their bioavailability, are therefore expected to increase with climate change (Yang et al., 2003; McKenzie et al., 2004; IPCC, 2013). Also, recurring natural and deliberate forest fires (often associated with land-use conversions), which are a major 
disturbance to the lake's watershed, would further increase soil erosion rates and exacerbate release of sediment-bound trace elements (Eva and Lambin, 2000). As a result, concerns about these threats to the lake led to the creation of the UN-funded Lake Tanganyika Biodiversity Project (LTBP, http://www.Itbp.org/) and the Lake Tanganyika Authority (LTA, http://Ita.iwlearn.org/).

These programs and similar efforts have provided a vehicle for a wide range of sustained scientific data collection on diverse topics, including climate change impacts, water quality, and land-use on the lake (Cohen et al., 1993; Tierney et al., 2010). They have resulted in new data on historic profiles of $\mathrm{Cd}, \mathrm{Fe}, \mathrm{Mo}, \mathrm{Re}$, and $\mathrm{U}$ in the lake's sediment (Brucker et al., 2011) and a report on $\mathrm{Hg}$ fluxes to the lake (Conaway et al., 2012). However, there are no comparable measurements of temporal changes of industrial trace elements (e.g., $\mathrm{Co}, \mathrm{Cu}, \mathrm{Pb}$, and $\mathrm{Zn}$ ) fluxes associated with mining and smelting operations and land-use changes around the lake.

To address those concerns, in addition to measuring the concentrations of trace elements, we included stable lead isotopic composition analyses to determine the sources and fate of $\mathrm{Pb}$ contamination in the lake (Ellam, 2010; Flegal et al., 2010). Lead isotopic composition data have been used to identify the combustion of leaded gasoline as the dominant source of $\mathrm{Pb}$ contamination in the $20^{\text {th }}$ century, which subsequently led to the phase-out of $\mathrm{Pb}$ from gasoline in many countries, including the United States (Nriagu, 1990; Needleman, 2000). Consequently, the objective of this study was to quantify trace element inputs, along with lead isotopic compositions, at two contrasting sites in Lake Tanganyika over the past two to four 
centuries to better understand the flux of natural and industrial trace elements into Lake Tanganyika.

\section{MATERIALS AND METHODS}

\subsection{Study Site and Sample Collection}

Lake Tanganyika is the world's second largest (in volume) and second deepest freshwater lake (Coulter and Spigel, 1991; Tierney et al., 2010). It covers an area of 32,600 km²; has an average depth of $570 \mathrm{~m}$, with a maximum depth of $1.47 \mathrm{~km}$; and is bordered by Burundi, Tanzania, Zambia, and the Democratic Republic of the Congo (Coulter and Spigel, 1991; Cohen et al., 2005a). The lake is an invaluable source of food and drinking water to millions of people that live around the lake (Molsa et al., 1999; Tierney et al., 2010), and it is surrounded by some of the world's fastest growing human populations, which could further impact the health of the lake (West, 2001; Than, 2011). 


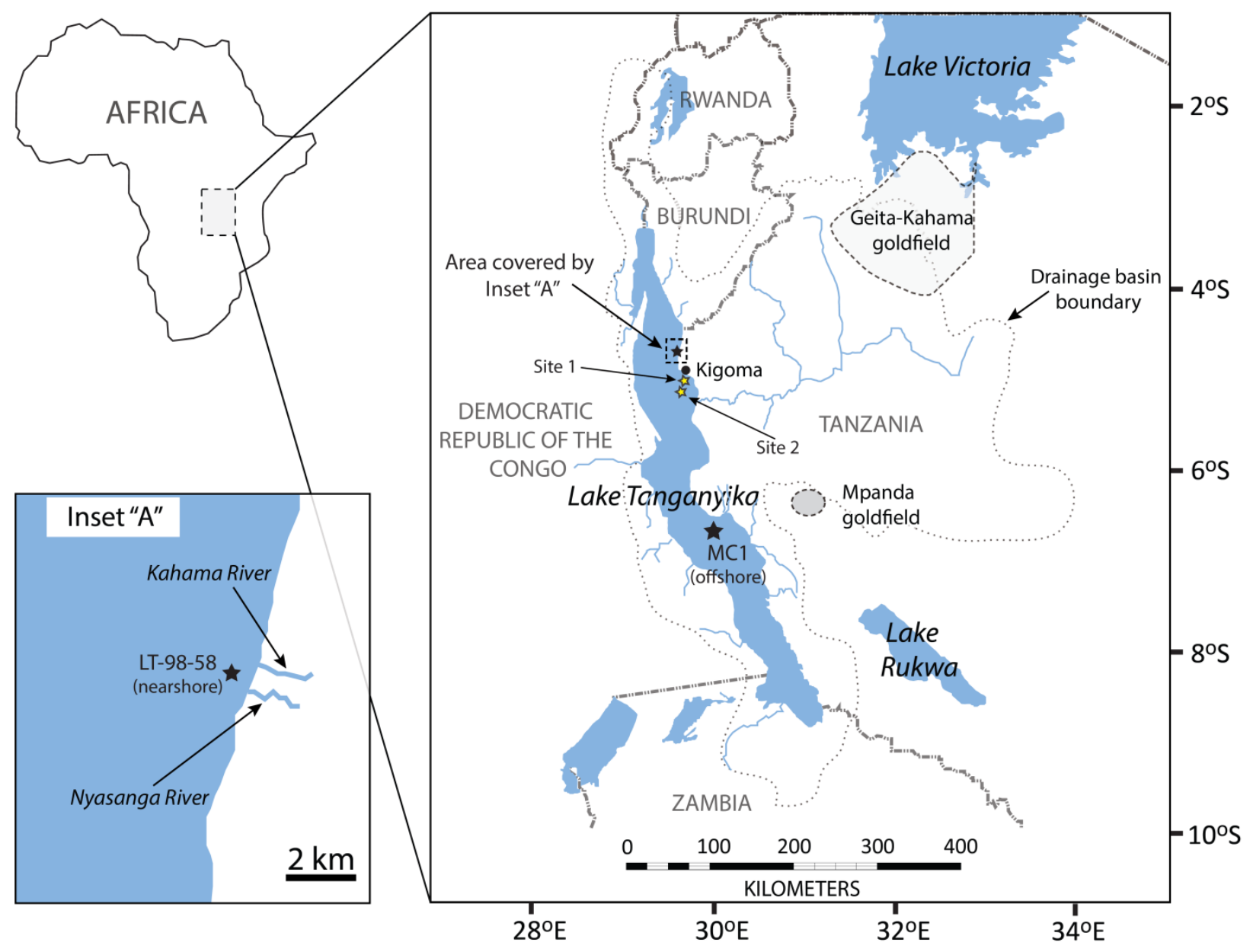

Fig. 1: Map showing sample collection sites from Lake Tanganyika in Africa and the approximate drainage basin of the lake (Adapted from Bergonzini et al. 1997 and Conaway et al. 2012). Also included on the map are the collection sites, Site 1 (72 m depth) and Site 2 (332 m depth), of sediment cores studied by Brucker et al. 2011.

Subsamples from two sediment cores, a nearshore core (LT-98-58) and an offshore core (MC1), collected from Lake Tanganyika with a Hedrick-Marrs multi-corer deployed from a ship were used for this study (Fig. 1). The cores were collected with intact sediment-water interface after an extensive mapping survey of the lake bottom as described elsewhere (Cohen et al., 2005a). The nearshore core $\left(4.6883^{\circ} \mathrm{S}, 29.6167^{\circ} \mathrm{E}\right)$ was collected in relatively shallow water (76 $\mathrm{m}$ ) just off the Nyasanga/Kahama delta region which drains a small $\left(\sim 3.8 \mathrm{~km}^{2}\right)$ sparsely populated $\left(<5\right.$ people per $\left.\mathrm{km}^{2}\right)$ area within the relatively pristine Gombe 
Stream National Park in northern Tanzania (Cohen et al., 2005a; McKee et al., 2005): a watershed that has been effectively uninhabited since the early 1960s. The offshore core $\left(6.5525^{\circ} \mathrm{S}, 29.9747^{\circ} \mathrm{E}\right)$ was collected in deep (309 m) water off the Kalya Platform in the relatively remote south-central part of the lake. The sediment cores were both dated with excess ${ }^{210} \mathrm{~Pb}$ (using constant rate of supply (CRS) model for core LT-98-58 and constant initial concentration ( $\mathrm{CIC}$ ) model for $\mathrm{MC} 1$ ) and ${ }^{14} \mathrm{C}$ using accelerator mass spectrometry. The age models and determination of sedimentation rates for Core LT-98-58 and Core MC1 are described in detail in McKee et al. (2005) and Tierney et al. (2010), respectively. These two sites differ dramatically in their depositional regimes; the nearshore site receives more direct, local inputs from relatively pristine sources whereas the offshore site integrates more dispersed inputs.

\subsection{Sample Processing and Analysis}

High purity (18.2 $\mathrm{M} \Omega \mathrm{cm}$ ) water (Milli-Q) and trace metal grade or ultrapure (2X subboiling quartz distilled) grade reagents were used for cleaning labware and processing samples. Thirty-seven (37) samples, including four (4) aliquots in triplicate, along with procedural blanks, National Bureau of Standards (NBS) Standard Reference Material (SRM) 1645, and NBS SRM 2704, were processed concurrently using established methods (Soto-Jimenez et al., 2006). Briefly, 0.3 to $0.5 \mathrm{~g}$ of sediment or SRM was transferred to a trace metal clean Teflon digestion vial, dried overnight at $65^{\circ} \mathrm{C}$, cooled, and weighed. The sediment was then refluxed in $10 \mathrm{~mL}$ of hot $\left(\sim 130^{\circ} \mathrm{C}\right)$ concentrated aqua regia $\left(\mathrm{HNO}_{3}+\mathrm{HCl}, 1: 3 \mathrm{v} / \mathrm{v}\right)$ in a closed vial overnight, dried, 
cooled, and re-dissolved in $10 \mathrm{~mL}$ of $1 \mathrm{M}$ ultrapure $\mathrm{HNO}_{3}$ (Odigie and Flegal, 2014). The "neartotal concentrations" of $\mathrm{Co}, \mathrm{Cu}, \mathrm{Ni}, \mathrm{Pb}$, and $\mathrm{Zn}$ in the digests were then determined with a Finnigan ELEMENT 2 high resolution inductively coupled plasma - mass spectrometer (HR ICPMS) using established methods (Dunlap et al., 2008). Lead isotopic compositions $\left({ }^{207} \mathrm{~Pb} /{ }^{204} \mathrm{~Pb}\right.$, ${ }^{206} \mathrm{~Pb} /{ }^{207} \mathrm{~Pb}$, and ${ }^{208} \mathrm{~Pb} /{ }^{207} \mathrm{~Pb}$ ) were measured separately, after optimizing the $\mathrm{Pb}$ concentrations of the solutions, with HR ICP-MS, as previously described (Odigie and Flegal, 2011; Zurbrick et al., 2013). Concentrations of $\mathrm{Al}, \mathrm{Fe}$, and $\mathrm{Mn}$ in the digests were then determined with a PerkinElmer Optima 4300 DV inductively coupled plasma - optical emission spectrometer (ICPOES). Internal standards were used to correct for instrumental drift during analyses, and concurrent measurements of National Institute of Standards and Technology (NIST) SRM 981 (common lead) were used to correct the lead isotopic ratios for instrumental fractionation (Kristensen et al., 2014). Isobaric interference of ${ }^{204} \mathrm{Hg}$ with ${ }^{204} \mathrm{~Pb}$ was corrected using established, state of the art methods, i.e., by concurrently measuring ${ }^{200} \mathrm{Hg}$ and ${ }^{202} \mathrm{Hg}$, calculating ${ }^{204} \mathrm{Hg}$ by assuming natural abundance $\left({ }^{204} \mathrm{Hg} /{ }^{202} \mathrm{Hg}=0.2298\right)$, and subtracting the ${ }^{204} \mathrm{Hg}$ counts from the total counts at $\mathrm{m} / \mathrm{z}=204\left({ }^{204} \mathrm{Hg}+{ }^{204} \mathrm{~Pb}\right)$, as detailed elsewhere $(\mathrm{Wu}$ and Boyle, 1997; Gallon et al., 2011; Zurbrick et al., 2013). The detection limit, digestion recovery, and analytical precision for each analyte are presented in Tables S1 to S4 (where " $\mathrm{S}$ " here and hereafter denotes that the table is in the supplementary material file). Enrichment factors (EFs) for each element were calculated by normalizing the concentration of the element in a sample to the average concentration of the element in pre-industrial (before 1890) samples from the sediment core (Nriagu et al., 1982; El Bilali et al., 2002). The fluxes of elements ( $\mu \mathrm{g} \mathrm{cm}^{-2} \mathrm{yr}^{-1}$ or

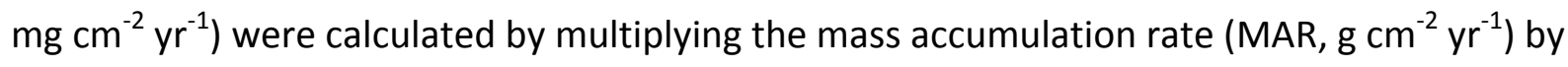


each element concentration $\left(\mu \mathrm{g} \mathrm{g}^{-1}\right.$ or $\mathrm{mg} \mathrm{g}^{-1}$ ). These elemental concentrations, fluxes, and enrichment factors are considered conservative because the digestion did not include treatment with concentrated $\mathrm{HF}$, which is needed for complete dissolution of refractory elements bound in aluminosilicate minerals. Concentrations of charcoal particles (>100 $\mu \mathrm{m})$ were previously determined for LT-98-58 using samples collected from a matched parallel core (Palacios-Fest et al., 2005) and for MC1 using subsamples collected from the core (Tierney et al., 2010).

\section{RESULTS AND DISCUSSION}

\subsection{Overview}

The "near total" concentrations of $\mathrm{Al}, \mathrm{Co}, \mathrm{Cu}, \mathrm{Fe}, \mathrm{Mn}, \mathrm{Ni}, \mathrm{Pb}$, and $\mathrm{Zn}$ for the two cores are listed in Table S5. Sediment fluxes of these elements, along with the ${ }^{206} \mathrm{~Pb} /{ }^{207} \mathrm{~Pb}$, ${ }^{207} \mathrm{~Pb} /{ }^{204} \mathrm{~Pb}$, and ${ }^{208} \mathrm{~Pb} /{ }^{207} \mathrm{~Pb}$ ratios of the sediment, are listed in Table S6. Temporal profiles for the concentrations of the elements and lead isotopic ratios are presented in the supplementary material file (Tables S5 and S6). Fluxes of trace elements at the offshore site (MC1) were consistently lower ( $\leq 10$-fold) than those at the nearshore site (LT-98-58), which was directly impacted by surface runoff and fluvial discharges from the Kahama and Nyasanga Rivers (Figs. 1 and 2). The latter site's relatively high individual element inputs corresponded with the relatively high mass accumulation rates (MARs) at that site, which were over an order of magnitude greater than those at the offshore site (Fig. 3a). However, trace element concentrations at both sites had comparable levels of enrichment, which were close to 1 , 
except for Zn, which showed recent increased input, although its EFs were still less than 5 and within the range of natural variability.
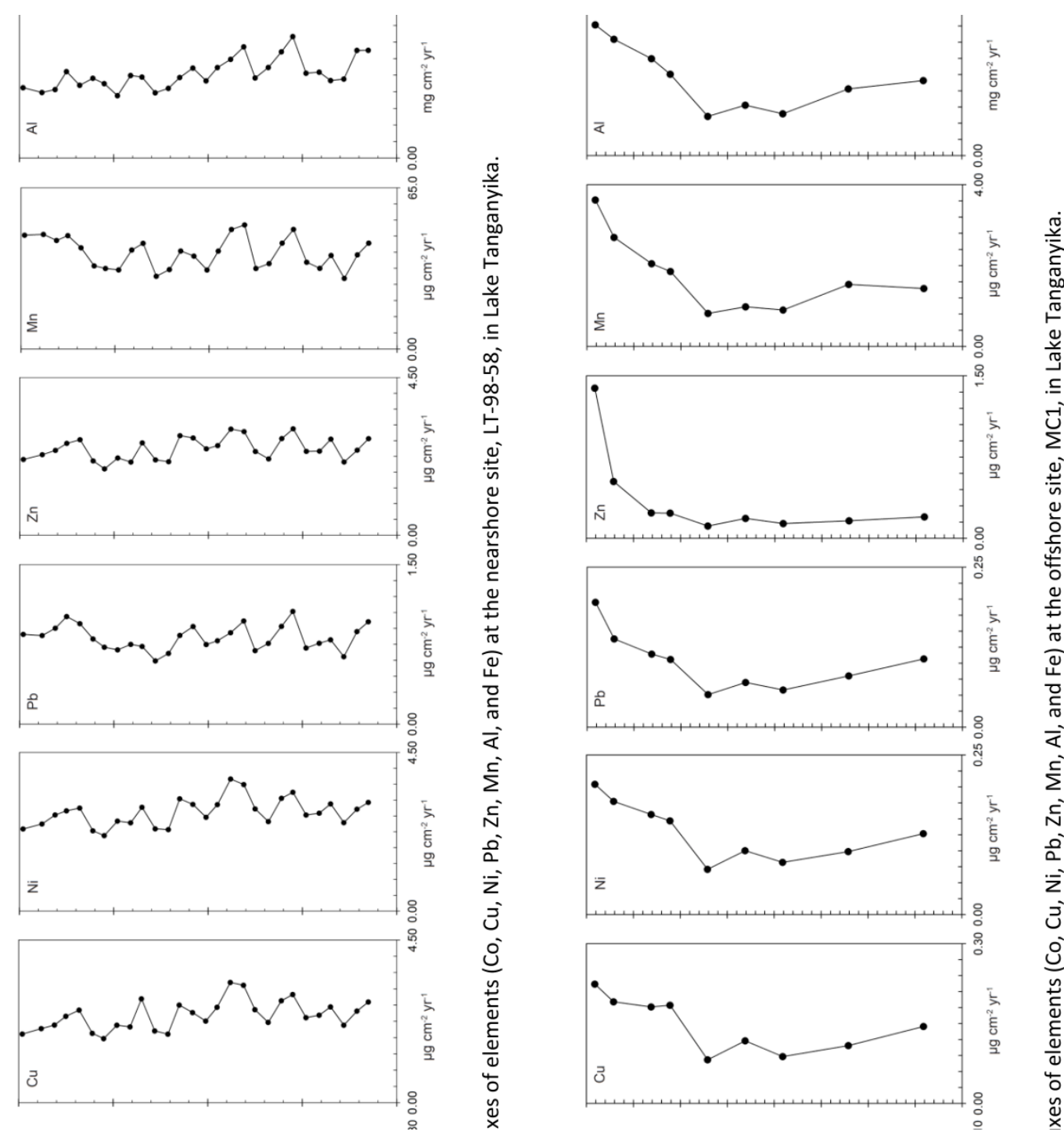

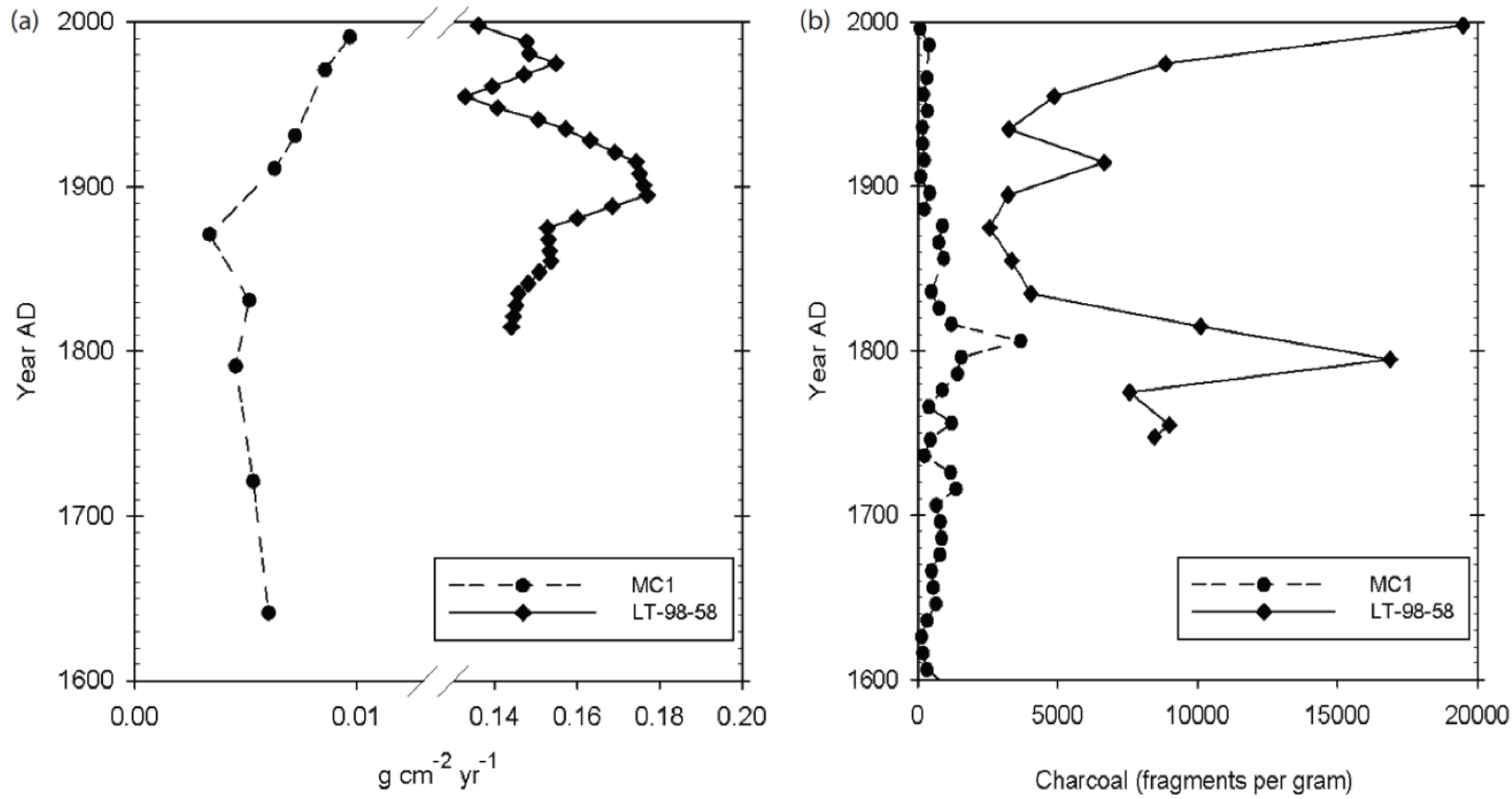

Fig. 3a: Mass accumulation rate (MAR, $\mathrm{g} \mathrm{cm}^{-2} \mathrm{yr}^{-1}$ ) plots for cores MC1 (offshore) and LT-98-58 (nearshore) (Adapted from Conaway et al. 2012, data from Tierney et al. 2010 and McKee et al. 2005).

Fig. 3b: Charcoal abundance profiles for MC1 (offshore site) and LT-98-58 (nearshore site) (Adapted from Conaway et al. 2012, data from Palacios-Fes et al. 2005 and Tierney et al. 2010).

\subsection{Nearshore Site (Core LT-98-58)}

The "near total" concentrations of $\mathrm{Cu}\left(16 \pm 2 \mu \mathrm{g} \mathrm{g}^{-1}\right.$, mean \pm standard deviation, $\left.\mathrm{n}=28\right)$ in the nearshore sediment core are comparable with that of $\mathrm{Cu}\left(21 \mu \mathrm{g} \mathrm{g}^{-1}\right)$ measured in nearshore sediment from Lake Tanganyika by Chale in 2002 , but the concentrations of $\mathrm{Pb}(5 \pm 1$ $\mu \mathrm{g} \mathrm{g}^{-1}$, mean \pm standard deviation, $\left.\mathrm{n}=28\right)$ and $\mathrm{Zn}\left(16 \pm 2 \mu \mathrm{g} \mathrm{g}^{-1}\right.$, mean \pm standard deviation, $\mathrm{n}=$ $28)$ in our nearshore core are substantially lower than those of $\mathrm{Pb}\left(14 \mu \mathrm{g} \mathrm{g}^{-1}\right)$ and $\mathrm{Zn}\left(28 \mu \mathrm{g} \mathrm{g}^{-1}\right)$ reported for nearshore sediment in that study (Chale, 2002). In contrast, Mn concentrations (253 $\pm 44 \mu \mathrm{g} \mathrm{g}^{-1}$, mean \pm standard deviation, $\mathrm{n}=28$ ) in our nearshore sediment core were substantially higher than the value $\left(73 \mu \mathrm{g} \mathrm{g}^{-1}\right)$ reported by Chale 2002 , but are comparable to Mn concentrations $\left(235 \pm 65 \mu \mathrm{g} \mathrm{g}^{-1}\right.$, mean \pm standard deviation, $\mathrm{n}=10$ ) measured in relatively 
pristine Zambian soil (Mihaljevic et al., 2011). Similarly, the concentrations of Al (30 $\pm 6 \mathrm{mg} \mathrm{g}^{-1}$, mean \pm standard deviation, $\mathrm{n}=28)$ and Fe $\left(33 \pm 5 \mathrm{mg} \mathrm{g}^{-1}\right.$, mean \pm standard deviation, $\left.\mathrm{n}=28\right)$ in the nearshore core are comparable to those of $\mathrm{Al}\left(54 \pm 19 \mathrm{mg} \mathrm{g}^{-1}\right.$, mean \pm standard deviation, $\mathrm{n}$ $=10)$ and Fe (44 $\pm 15 \mathrm{mg} \mathrm{g}^{-1}$, mean \pm standard deviation, $\left.\mathrm{n}=10\right)$ measured by Brucker et al. (2011) in a sediment core collected at a comparable depth (72 m) from the Luiche Platform in Lake Tanganyika. Averages of the measurements by Brucker et al. (2011) are higher than those of the elements ( $\mathrm{Al}$ and Fe) we measured, presumably due to the different digestion methods (total versus near-total) employed in the two studies.

Fluxes of $\mathrm{Co}, \mathrm{Cu}, \mathrm{Mn}, \mathrm{Ni}, \mathrm{Pb}$, and $\mathrm{Zn}$ correlated (simple linear regressions) positively with those of Fe $(r=0.77$ to $0.88, p<0.01, n=28)$ at the nearshore site (Table S7). None of the fluxes systematically changed over the last two centuries (1815 to 1998) (Fig. 2a), and all of their EFs were consistently low $(<5)$. Consequently, the sources of those trace elements (Co, $\mathrm{Cu}, \mathrm{Mn}, \mathrm{Ni}, \mathrm{Pb}$ and $\mathrm{Zn})$, as well as those of $\mathrm{Al}$ and $\mathrm{Fe}$, at the nearshore site are primarily attributed to the weathering of natural sources, rather than industrial inputs, even during the $20^{\text {th }}$ century.

Those relatively consistent temporal trends of natural element fluxes are comparable to the relatively conservative trends reported for the concentration and accumulation rate of total organic matter (TOC) at the site (Palacios-Fest et al., 2005). Trace elements sorb to organic matter, which could substantially influence their behavior in terrestrial and aquatic systems (Schwab et al., 2008; Hartland et al., 2011).

These conservative temporal trends were expected because the nearshore site: (i) drains a basin with a relatively small human population $\left(<5\right.$ people per $\mathrm{km}^{2}$ ), (ii) has a relatively Page 14 of 26 
low level of disturbance - including deforestation in its watershed, and (iii) has not had major soil erosion pulses within its watershed since the late $19^{\text {th }}$ century (Cohen et al., 2005a; Cohen et al., 2005b; O'Reilly et al., 2005).

In contrast to the element fluxes, there were pronounced temporal changes in charcoal fluxes, which increased by $\sim 500 \%$ between 1935 to 1998 , to sediment at the nearshore site that do not appear to be from local inputs (Palacios-Fest et al., 2005). Specifically, charcoal fluxes were relatively high at the nearshore site (2574 - 19473 fragments per gram) compared to those at the offshore site (90 - 3680 fragments per gram), which were relatively constant throughout the core (Fig. 3b). Since the site abuts the protected Gombe Stream National Park, that increase in charcoal fluxes has been attributed to regional, rather than local, increases in anthropogenic activities around Lake Tanganyika during the $20^{\text {th }}$ century (Palacios-Fest et al., 2005; Conaway et al., 2012). The regional source of charcoal versus the apparently local source of elements in sediment at the nearshore site was also evidenced by the relatively low and statistically insignificant correlations between the fluxes of most of those elements $(\mathrm{Al}, \mathrm{Co}, \mathrm{Cu}$, $\mathrm{Fe}, \mathrm{Ni}, \mathrm{Pb}$, and $\mathrm{Zn})$ and that of charcoal $(r=-0.35$ to $0.49, \mathrm{n}=10, \mathrm{p}>0.1)$. Consequently, the naturally high rates of sedimentation at the nearshore site (MAR $=0.13$ to $0.18 \mathrm{~g} \mathrm{~cm}^{-2} \mathrm{yr}^{-1}$ ) swamp the relatively small increases in sediment fluxes associated with fires and anthropogenic activities over the last century. But those increases are apparent in the offshore site, where sedimentation rates are over an order of magnitude lower (MAR $=3.4$ to $9.7 \mathrm{mg} \mathrm{cm}^{-2} \mathrm{yr}^{-1}$ ), as discussed in section 3.3 (Offshore Site). 


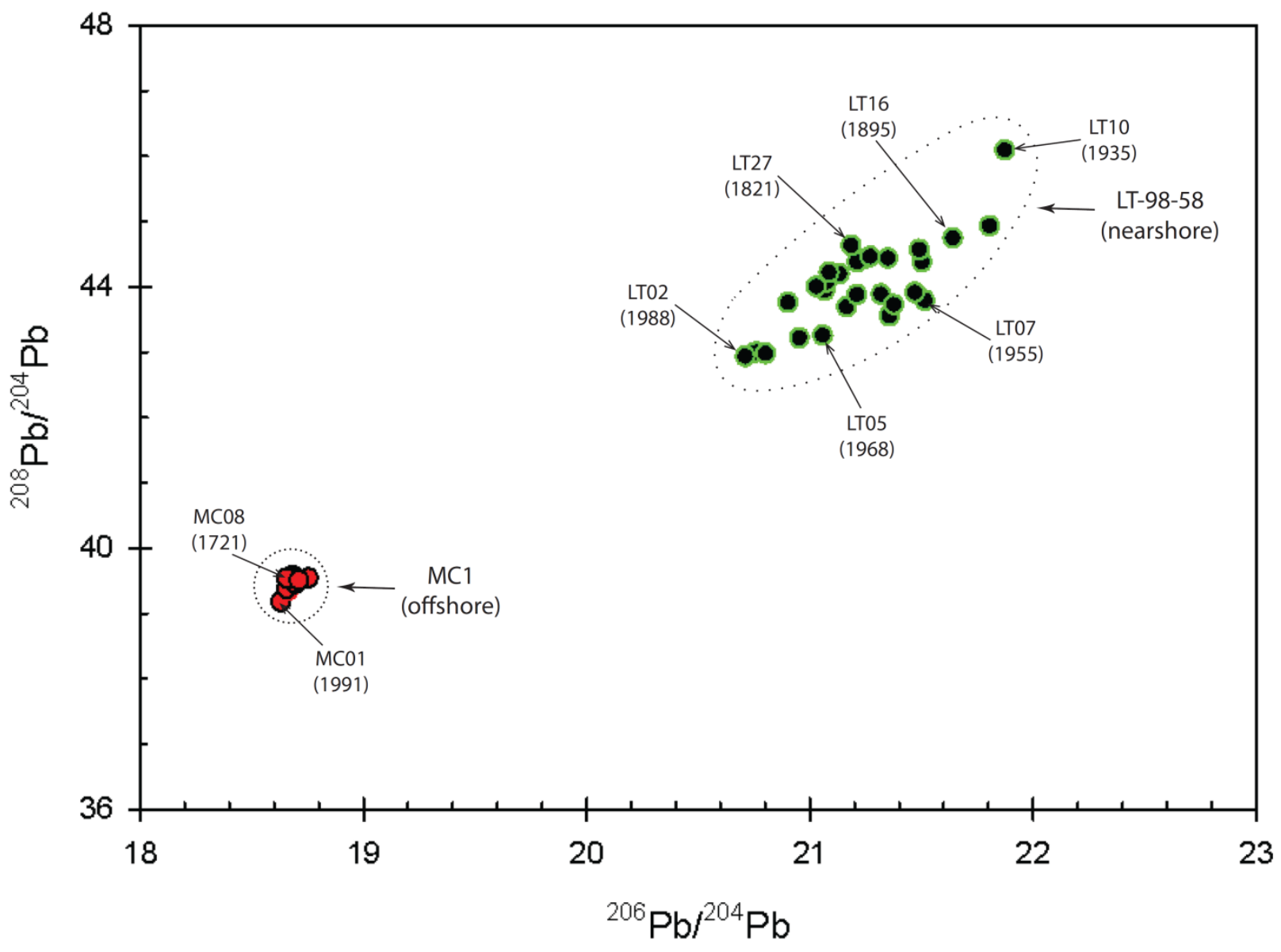

Fig. 4: Lead isotopic composition $\left({ }^{206} \mathrm{~Pb} /{ }^{204} \mathrm{~Pb}:{ }^{208} \mathrm{~Pb} /{ }^{204} \mathrm{~Pb}\right.$ ) of sediment core samples (LT-98-58 and MC1) collected from Lake Tanganyika, Africa. LT02 denotes Core LT-98-58 (nearshore site) and a depth of 1 to 2 (1.5) $\mathrm{cm}$ and so forth. MC denotes Core MC1 (offshore site). 


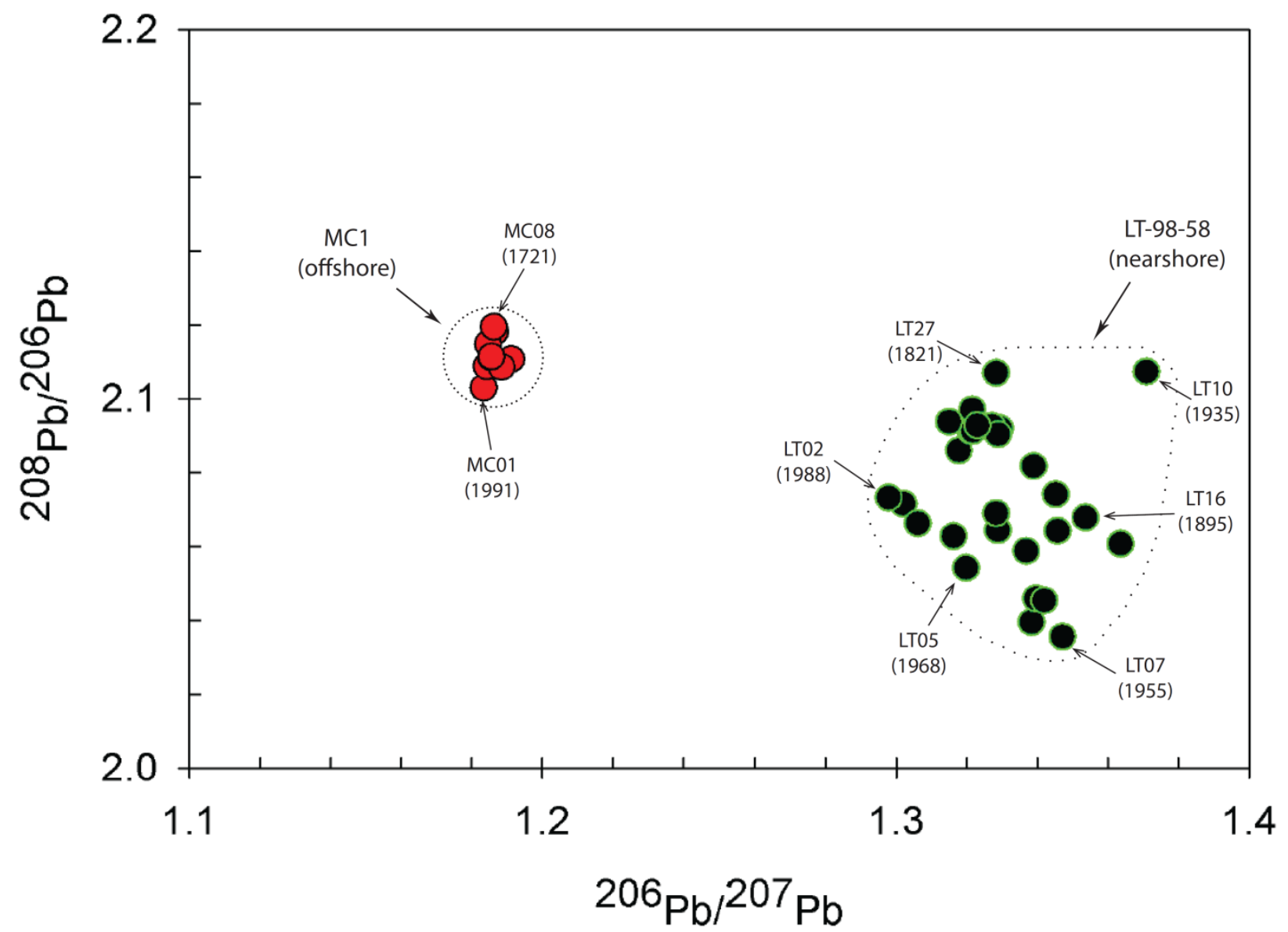

Fig. 5: Lead isotopic composition ( ${ }^{206} \mathrm{~Pb} /{ }^{207} \mathrm{~Pb}:{ }^{208} \mathrm{~Pb} /{ }^{206} \mathrm{~Pb}$ ) of sediment core samples (LT-98-58 and MC1) collected from Lake Tanganyika, Africa. LT02 denotes Core LT-98-58 (nearshore site) and a depth of 1 to 2 (1.5) $\mathrm{cm}$ and so forth. MC denotes Core MC1 (offshore site).

The isotopic compositions of Pb in sediment at the nearshore site (Figs. 4 and 5), which are assumed to be predominantly characteristic of relatively uncontaminated sediment in the Nyasanga/Kahama drainage basin, are markedly different from those of $\mathrm{Pb}$ at the offshore site of the lake. Small temporal changes in the lead isotopic compositions suggest that the site could have received $\mathrm{Pb}$ from anthropogenic sources. However, the influence of that deposition on the flux of $\mathrm{Pb}$ at the site appears to be minimal. Consequently, the relative consistency of the isotopic ratios of $\mathrm{Pb}$ over the past two centuries at the nearshore site (Figs. 4 and 5) 
suggests that the $\mathrm{Pb}$ is primarily from local, natural sources. The predominantly local sources of $\mathrm{Pb}$ (and other trace elements by association) was corroborated by the statistically significant ( $\mathrm{p}$ $<0.05$, t-test) positive correlations between the fluxes of trace elements and those of Fe as previously discussed (Table S7). Unfortunately, lead isotopic composition data on the Lake Tanganyika area are limited; thus, a comprehensive comparison of our data to others was not possible.

\subsection{Offshore Site (Core MC1)}

The "near total" concentrations of $\mathrm{Cu}\left(23 \pm 3 \mu \mathrm{g} \mathrm{g}{ }^{-1}\right.$, mean \pm standard deviation, $\left.\mathrm{n}=9\right)$, $\mathrm{Pb}\left(16 \pm 2 \mu \mathrm{g} \mathrm{g}^{-1}\right.$, mean \pm standard deviation, $\left.\mathrm{n}=9\right)$, and $\mathrm{Zn}\left(49 \pm 37 \mu \mathrm{g} \mathrm{g}^{-1}\right.$, mean \pm standard deviation, $\mathrm{n}=9)$ in the offshore sediment core are similar to those of $\mathrm{Cu}\left(21 \mu \mathrm{g} \mathrm{g}^{-1}\right), \mathrm{Pb}\left(14 \mu \mathrm{g} \mathrm{g}^{-}\right.$ $\left.{ }^{1}\right)$, and $\mathrm{Zn}\left(28 \mu \mathrm{g} \mathrm{g}^{-1}\right)$ measured in nearshore sediment from Lake Tanganyika by Chale 2002, but are substantially higher than the concentrations of $\mathrm{Cu}\left(3.6 \mu \mathrm{g} \mathrm{g}^{-1}\right), \mathrm{Pb}\left(1.4 \mu \mathrm{g} \mathrm{g}^{-1}\right)$, and $\mathrm{Zn}(2.2 \mu \mathrm{g}$ $\left.\mathrm{g}^{-1}\right)$ he measured in offshore sediment. The Mn concentrations $\left(269 \pm 58 \mu \mathrm{g} \mathrm{g}^{-1}\right.$, mean \pm standard deviation, $n=9$ ) in the offshore sediment core from our study are significantly $(p<$ 0.01 , t-test) higher than the value $\left(75 \mu \mathrm{g} \mathrm{g}^{-1}\right)$ reported by Chale 2002 , but are similar to $\mathrm{Mn}$ concentrations ( $235 \pm 65 \mu \mathrm{g} \mathrm{g}^{-1}$, mean \pm standard deviation, $\mathrm{n}=10$ ) measured in relatively pristine Zambian soil (Mihaljevic et al., 2011). Concentrations of Al (60 $\pm 8 \mathrm{mg} \mathrm{g}^{-1}$, mean \pm standard deviation, $\mathrm{n}=9)$ and Fe $\left(40 \pm 6 \mathrm{mg} \mathrm{g}^{-1}\right.$, mean \pm standard deviation, $\left.\mathrm{n}=9\right)$ in the offshore sediment are within the ranges of those of $\mathrm{Al}\left(72 \pm 21 \mathrm{mg} \mathrm{g}^{-1}\right.$, mean \pm standard deviation, $\mathrm{n}=7)$ and Fe $\left(51 \pm 16 \mathrm{mg} \mathrm{g}^{-1}\right.$, mean \pm standard deviation, $\left.\mathrm{n}=7\right)$ measured by Brucker et al. (2011) in a sediment core collected at a comparable depth (332 m) off the Luiche Platform 
in Lake Tanganyika. The Al and Fe measured in these studies are considered to be natural since these elements are naturally abundant and relatively difficult to measurably increase through contamination. Thus, the strong positive correlations between the concentrations of the other elements and those of Fe indicate that these elements are predominantly from local, natural sources.

As at the nearshore site, down core fluxes of $\mathrm{Co}, \mathrm{Cu}, \mathrm{Mn}, \mathrm{Ni}, \mathrm{Pb}$, and $\mathrm{Zn}$ correlated positively with those of Fe ( $r=0.77$ to $0.99, \mathrm{p} \leq 0.02, \mathrm{n}=9)$ at the offshore site (Table S7). In contrast to the nearshore site, those fluxes systematically varied over the past four centuries (1641 to 1991) (Fig. 2b). For example, the fluxes of $\mathrm{Al}, \mathrm{Co}, \mathrm{Cu}, \mathrm{Fe}, \mathrm{Mn}, \mathrm{Ni}, \mathrm{Pb}$, and $\mathrm{Zn}$ increased by approximately $200 \%, 200 \%, 200 \%, 200 \%, 300 \%, 200 \%, 300 \%$, and $1000 \%$, respectively, from 1871 to 1991 . Regardless, the strong positive and statistically significant correlations between the fluxes of $\mathrm{Co}, \mathrm{Cu}, \mathrm{Mn}, \mathrm{Ni}$, and $\mathrm{Pb}$ and those of $\mathrm{Fe}(r=0.95$ to $1.00, \mathrm{p}<0.02, \mathrm{n}=5$ ) over the past two centuries (1871 to 1991) as well as the low EFs $(<5)$ of those elements at the offshore site indicate that the mid-lake sediment core is a sensitive and useful recorder of land use changes.

The one, modest, exception is $\mathrm{Zn}$. Correlation between the flux of $\mathrm{Zn}$ and that of Fe $(r=$ 0.75 ) was positive, but not statistically significant $(p>0.1, n=5)$ during that period (1871 to 1991). Still, the recent (1931 to 1991) steep increase in the flux of Zn suggests that Zn was enriched at this site, possibly by industrial activities.

The MAR at the offshore site also increased during the past two centuries (1871 to 1991, Fig. 3a), presumably from accelerated erosion rates associated with substantial deforestation ( 40 to $60 \%$ ) that occurred in the lake's watersheds mostly in the $20^{\text {th }}$ century 
(Cohen et al., 1993). Correlations between the fluxes of $\mathrm{Al}, \mathrm{Co}, \mathrm{Cu}, \mathrm{Fe}, \mathrm{Mn}, \mathrm{Ni}, \mathrm{Pb}$, and $\mathrm{Zn}$ and $\operatorname{MAR}(r=0.82$ to $0.98, n=9)$ were statistically significant $(p<0.01, t$-test), suggesting that the increase in fluxes of elements is due to local disturbance of sediment in the lake's drainage basin. Therefore, we attribute the pronounced temporal increases in trace element fluxes at the offshore site primarily to increases in erosion rates associated with land-use changes in the lake's drainage basins.

The temporal consistency of lead isotopic compositions (Figs. 4 and 5) of sediment at the offshore site over the past four centuries also indicates that the temporal increases in $\mathrm{Pb}$ (and most other trace elements by association) originated predominantly from increases in local, natural fluxes. The apparent local sources of those fluxes were further evidenced by the positive correlations of their fluxes with those of Fe.

\section{CONCLUSIONS}

The concentrations of trace elements ( $\mathrm{Co}, \mathrm{Cu}, \mathrm{Mn}, \mathrm{Ni}, \mathrm{Pb}$, and $\mathrm{Zn})$, the significant positive correlations of their fluxes with those of $\mathrm{Fe}$, and their low respective enrichment factors $(<5)$ in Lake Tanganyika all suggest that these trace elements were predominantly derived from local sources. The spatial differences between the fluxes of respective trace elements (Figs. 2a and 2b) at the nearshore (LT-98-58) and offshore (MC1) sites are tentatively attributed to several factors, including: proximity to shore (MC1 is much farther from direct terrestrial sediment sources), water conditions (e.g., DO concentrations at the different water depths: $76 \mathrm{~m}$ at LT-98-58 and $309 \mathrm{~m}$ at MC1), sediment focusing, and the relative levels of

disturbance (e.g., increased erosion rates associated with deforestation) (Conaway et al., 2012). 
Spatially different, but predominantly consistent lead isotopic compositions at the two sites over time indicate that the $\mathrm{Pb}$ (and other trace elements by association) originated from relatively distinct sources. This spatial difference in $\mathrm{Pb}$ isotopic compositions could have resulted from an elevated atmospheric contribution of $\mathrm{Pb}$ to the offshore site, compared to the nearshore site. Concentrations of some elements measured in this study are similar to previously published values in terrestrial and lacustrine sediment from and around Lake Tanganyika, including Lake Victoria, another large lake in the same region (Kishe and Machiwa, 2003; Brucker et al., 2011). Therefore, these data are coherent.

Consequently, the impact of human activities, especially those related to land use and development, on the fluxes of trace elements was minimal at the nearshore site, presumably because of the naturally high sediment influx to the site and its relatively pristine drainage area. But that impact was pronounced at the offshore site. The results indicate that the offshore site is a more sensitive and reliable recorder of environmental changes within the lake's basin. Temporal changes in trace element fluxes at the offshore site appear to be primarily due to land use changes that increase erosion - rather than additional inputs of industrial elements. These land use-driven changes in the fluxes of elements contrast with the increase in $\mathrm{Hg}$ fluxes at both sites that were attributed predominantly to global industrial emissions (Conaway et al., 2012).

In summary, results from this study indicate that the impacts of industrial waste discharged to the northern reach of the lake and wildfires around the lake on the fluxes of trace elements at both sites are relatively limited. However, the projected global increase in wildfire intensity and frequency in response to climate change, along with increasing population in the Page 21 of 26 
lake's drainage basin, could substantially impact the trace element fluxes to the lake over the next century, as recently observed elsewhere (Odigie and Flegal, 2011; Stein et al., 2012; Odigie and Flegal, 2014). Consequently, studies aimed at further characterizing different natural and industrial sources of elements to Lake Tanganyika are needed to improve our understanding of the extent of anthropogenic perturbations in the lake and its basin.

\section{ACKNOWLEDGMENTS}

The authors are grateful to Christopher H. Conaway, Céline Gallon, Christina Richardson, and two anonymous reviewers for their insightful suggestions to earlier drafts of this manuscript; Rob Franks of UCSC for help with samples analyses, and all members of the UCSC WIGS Laboratory, especially Sharon Hibdon, for her support with this project. Cores described in this project were collected with support from the Lake Tanganyika Biodiversity Project, and the NSF-support Nyanza Project (NSF-ATM0223920). This work was partly supported by Department of Energy (DOE) Office of Science Graduate Fellowship Program. All opinions expressed in this work are the authors' and do not necessarily reflect the policies and views of the DOE Office of Science. PWS thanks the USGS CMG Program for continued support.

\section{REFERENCES}

Banza, C.L.N., Nawrot, T.S., Haufroid, V., Decree, S., De Putter, T., Smolders, E., Kabyla, B.I., Luboya, O.N., Ilunga, A.N., Mutombo, A.M., Nemery, B., 2009. High human exposure to cobalt and other metals in Katanga, a mining area of the Democratic Republic of Congo. Environ. Res. 109, 745752.

Bizimana, M., Duchafour, H., 1991. A drainage basin management study: The case of the Ntihangwa River Basin. In: Report of the First International Conference on Conservation and Biodiversity Support Program (ed. A. S. Cohen). Washington, D.C., pp. 43-45.

Blacksmith Institute, 2007. The world's worst polluted places. In The Top Ten of The Dirty Thirty. Retrieved on September 12, 2012 from http://www.blacksmithinstitute.org/wwpp2007/finalReport2007.pdf. 
Brucker, R.P., McManus, J., Severmann, S., Owens, J., Lyons, T.W., 2011. Trace metal enrichments in Lake Tanganyika sediments: Controls on trace metal burial in lacustrine systems. Geochim. Cosmochim. Acta 75, 483-499.

CDC, 2012. Blood lead levels in children, Retrieved on October 16, 2013 from http://www.cdc.gov/nceh/lead/ACCLPP/Lead_Levels_in_Children_Fact_Sheet.pdf., p. 2.

Chale, F.M.M., 2002. Trace metal concentrations in water, sediments and fish tissue from Lake Tanganyika. Sci. Total Environ. 299, 115-121.

Cohen, A.S., Bills, R., Cocquyt, C.Z., Caljon, A.G., 1993. The impact of sediment pollution on biodiversity in Lake Tanganyika. Conserv. Biol. 7, 667-677.

Cohen, A.S., Palacios-Fest, M.R., McGill, J., Swarzenski, P.W., Verschuren, D., Sinyinza, R., Songori, T., Kakagozo, B., Syampila, M., O'Reilly, C.M., Alin, S.R., 2005a. Paleolimnological investigations of anthropogenic environmental change in Lake Tanganyika: I. An introduction to the project. J. Paleolimnol. 34, 1-18.

Cohen, A.S., Palacios-Fest, M.R., Msaky, E.S., Alin, S.R., McKee, B., O'Reilly, C.M., Dettman, D.L., Nkotagu, H., Lezzar, K.E., 2005b. Paleolimnological investigations of anthropogenic environmental change in Lake Tanganyika: IX. Summary of paleorecords of environmental change and catchment deforestation at Lake Tanganyika and impacts on the Lake Tanganyika ecosystem. J. Paleolimnol. 34, 125-145.

Conaway, C.H., Swarzenski, P.W., Cohen, A.S., 2012. Recent paleorecords document rising mercury contamination in Lake Tanganyika. Appl. Geochem. 27, 352-359.

Coulter, G.W., Spigel, R.H., 1991. Hydrodynamics. In Lake Tanganyika and its Life (ed. G. W. Coulter). Oxford University Press, New York. pp. 49-75, p. 354.

Dunlap, C.E., Alpers, C.N., Bouse, R., Taylor, H.E., Unruh, D.M., Flegal, A.R., 2008. The persistence of lead from past gasoline emissions and mining drainage in a large riparian system: Evidence from lead isotopes in the Sacramento River, California. Geochim. Cosmochim. Acta 72, 5935-5948.

El Bilali, L., Rasmussen, P.E., Hall, G.E.M., Fortin, D., 2002. Role of sediment composition in trace metal distribution in lake sediments. Appl. Geochem. 17, 1171-1181.

Ellam, R.M., 2010. The graphical presentation of lead isotope data for environmental source apportionment. Sci. Total Environ. 408, 3490-3492.

Ettler, V., Mihaljevic, M., Kribek, B., Majer, V., Sebek, O., 2011. Tracing the spatial distribution and mobility of metal/metalloid contaminants in Oxisols in the vicinity of the Nkana copper smelter, Copperbelt province, Zambia. Geoderma 164, 73-84.

Eva, H., Lambin, E.F., 2000. Fires and land-cover change in the tropics: A remote sensing analysis at the landscape scale. J. Biogeogr. 27, 765-776.

Flegal, A.R., Gallon, C., Hibdon, S., Kuspa, Z.E., Laporte, L.F., 2010. Declining-but persistent-atmospheric contamination in Central California from the resuspension of historic leaded gasoline emissions as recorded in the lace lichen (Ramalina menziesii Taylor) from 1892 to 2006. Environ. Sci. Technol. 44, 5613-5618.

Gallon, C., Ranville, M.A., Conaway, C.H., Landing, W.M., Buck, C.S., Morton, P.L., Flegal, A.R., 2011. Asian industrial lead inputs to the North Pacific evidenced by lead concentrations and isotopic compositions in surface waters and aerosols. Environ. Sci. Technol. 45, 9874-9882.

Hartland, A., Fairchild, I.J., Lead, J.R., Zhang, H., Baalousha, M., 2011. Size, speciation and lability of NOM-metal complexes in hyperalkaline cave dripwater. Geochim. Cosmochim. Acta 75, 75337551.

IPCC, 2013. Climate Change 2013: The Physical Science Basis. Cambridge Univ. Press, New York. Kishe, M.A., Machiwa, J.F., 2003. Distribution of heavy metals in sediments of Mwanza Gulf of Lake Victoria, Tanzania. Environ. Int. 28, 619-625. 
Kristensen, L.J., Taylor, M.P., Odigie, K.O., Hibdon, S.A., Flegal, A.R., 2014. Lead isotopic compositions of ash sourced from Australian bushfires. Environ. Pollut. 190, 159-165.

Marwa, E.M.M., Meharg, A.A., Rice, C.M., 2012. Risk assessment of potentially toxic elements in agricultural soils and maize tissues from selected districts in Tanzania. Sci. Total Environ. 416, 180-186.

McKee, B.A., Cohen, A.S., Dettman, D.L., Palacios-Fest, M.R., Alin, S.R., Ntungumburanye, G., 2005. Paleolimnological investigations of anthropogenic environmental change in Lake Tanganyika: II. Geochronologies and mass sedimentation rates based on C-14 and Pb-210 data. J. Paleolimnol. 34, 19-29.

McKenzie, D., Gedalof, Z., Peterson, D.L., Mote, P., 2004. Climatic change, wildfire, and conservation. Conserv. Biol. 18, 890-902.

Mihaljevic, M., Ettler, V., Sebek, O., Sracek, O., Kribek, B., Kyncl, T., Majer, V., Veselovsky, F., 2011. Lead isotopic and metallic pollution record in tree rings from the Copperbelt mining-smelting area, Zambia. Water Air Soil Pollut. 216, 657-668.

Molsa, H., Reynolds, J.E., Coenen, E.J., Lindqvist, O.V., 1999. Fisheries research towards resource management on Lake Tanganyika. Hydrobiologia 407, 1-24.

Nakayama, S.M.M., Ikenaka, Y., Hamada, K., Muzandu, K., Choongo, K., Teraoka, H., Mizuno, N., Ishizuka, M., 2011. Metal and metalloid contamination in roadside soil and wild rats around a $\mathrm{Pb}-\mathrm{Zn}$ mine in Kabwe, Zambia. Environ. Pollut. 159, 175-181.

Needleman, H.L., 2000. The removal of lead from gasoline: Historical and personal reflections. Environ. Res. 84, 20-35.

Nriagu, J.O., 1990. The rise and fall of leaded gasoline. Sci. Total Environ. 92, 13-28.

Nriagu, J.O., 1992. Toxic metal pollution in Africa. Sci. Total Environ. 121, 1-37.

Nriagu, J.O., 1996. A history of global metal pollution. Science 272, 223-224.

Nriagu, J.O., Pacyna, J.M., 1988. Quantitative assessment of worldwide contamination of air, water and soils by trace metals. Nature 333, 134-139.

Nriagu, J.O., Wong, H.K.T., Coker, R.D., 1982. Deposition and chemistry of pollutant metals in lakes around the smelters at Sudbury, Ontario. Environ. Sci. Technol. 16, 551-560.

O'Reilly, C.M., Alin, S.R., Plisnier, P.D., Cohen, A.S., McKee, B.A., 2003. Climate change decreases aquatic ecosystem productivity of Lake Tanganyika, Africa. Nature 424, 766-768.

O'Reilly, C.M., Dettman, D.L., Cohen, A.S., 2005. Paleolimnological investigations of anthropogenic environmental change in Lake Tanganyika: VI. Geochemical indicators. J. Paleolimnol. 34, 85-91.

Odigie, K.O., Flegal, A.R., 2011. Pyrogenic remobilization of historic industrial lead depositions. Environ. Sci. Technol. 45, 6290-6295.

Odigie, K.O., Flegal, A.R., 2014. Trace metal inventories and lead isotopic composition chronicle a forest fire's remobilization of industrial contaminants deposited in the Angeles National Forest. PLoS ONE 9(9): e107835. doi:10.1371/journal.pone.0107835.

Palacios-Fest, M.R., Cohen, A.S., Lezzar, K., Nahimana, L., Tanner, B.M., 2005. Paleolimnological investigations of anthropogenic environmental change in Lake Tanganyika: III. Physical stratigraphy and charcoal analysis. J. Paleolimnol. 34, 31-49.

Quinton, J.N., Catt, J.A., 2007. Enrichment of heavy metals in sediment resulting from soil erosion on agricultural fields. Environ. Sci. Technol. 41, 3495-3500.

Sañudo-Wilhelmy, S.A., Flegal, A.R., 1994. Temporal variations in lead concentrations and isotopic composition in the Southern California Bight. Geochim. Cosmochim. Acta 58, 3315-3320.

Schwab, A.P., Zhu, D.S., Banks, M.K., 2008. Influence of organic acids on the transport of heavy metals in soil. Chemosphere 72, 986-994. 
Soto-Jimenez, M.F., Hibdon, S.A., Rankin, C.W., Aggarawl, J., Ruiz-Fernandez, A.C., Paez-Osuna, F., Flegal, A.R., 2006. Chronicling a century of lead pollution in Mexico: Stable lead isotopic composition analyses of dated sediment cores. Environ. Sci. Technol. 40, 764-770.

Stein, E.D., Brown, J.S., Hogue, T.S., Burke, M.P., Kinoshita, A., 2012. Stormwater contaminant loading following southern California wildfires. Environ. Toxicol. Chem. 31, 2625-2638.

Tembo, B.D., Sichilongo, K., Cernak, J., 2006. Distribution of copper, lead, cadmium and zinc concentrations in soils around Kabwe town in Zambia. Chemosphere 63, 497-501.

Than, K., 2011. "Ocean" creatures that evolved in huge lake under threat, National Geographic Daily News. Retrieved on May 17, 2014 from http://news.nationalgeographic.com/news/2011/12/111201-lake-tanganyika-evolution-lakesoceans-environment-science/.

Tierney, J.E., Mayes, M.T., Meyer, N., Johnson, C., Swarzenski, P.W., Cohen, A.S., Russell, J.M., 2010. Late-twentieth-century warming in Lake Tanganyika unprecedented since AD 500. Nature Geosci. 3, 422-425.

Warren, L.J., 1981. Contamination of sediments by lead, zinc and cadmium - a review. Environ. Pollut. B 2, 401-436.

Wells, T.M., Cohen, A.S., Park, L.E., Dettman, D.L., McKee, B.A., 1999. Ostracode stratigraphy and paleoecology from surficial sediments of Lake Tanganyika, Africa. J. Paleolimnol. 22, 259-276.

West, K., 2001. Lake Tanganyika: Results and experiences of the UNDP/GEF Conservation Initiative (RAF/92/G32) in Burundi, D.R. Congo, Tanzania, and Zambia., Retrieved on September 13, 2012 from http://iwlearn.net/iw-projects/398/reports/. p. 138.

Wu, J., Boyle, E.A., 1997. Low blank preconcentration technique for the determination of lead, copper, and cadmium in small-volume seawater samples by Isotope Dilution ICPMS. Anal. Chem. 69, 2464-2470.

Yabe, J., Nakayama, S.M.M., Ikenaka, Y., Muzandu, K., Ishizuka, M., Umemura, T., 2011. Uptake of lead, cadmium, and other metals in the liver and kidneys of cattle near a lead-zinc mine in Kabwe, Zambia. Environ. Toxicol. Chem. 30, 1892-1897.

Yang, D.W., Kanae, S., Oki, T., Koike, T., Musiake, K., 2003. Global potential soil erosion with reference to land use and climate changes. Hydrol. Processes 17, 2913-2928.

Yang, H.D., Engstrom, D.R., Rose, N.L., 2010. Recent changes in atmospheric mercury deposition recorded in the sediments of remote equatorial lakes in the Rwenzori Mountains, Uganda. Environ. Sci. Technol. 44, 6570-6575.

Zurbrick, C.M., Gallon, C., Flegal, A.R., 2013. A new method for stable lead isotope extraction from seawater. Anal. Chim. Acta 800, 29-35. 


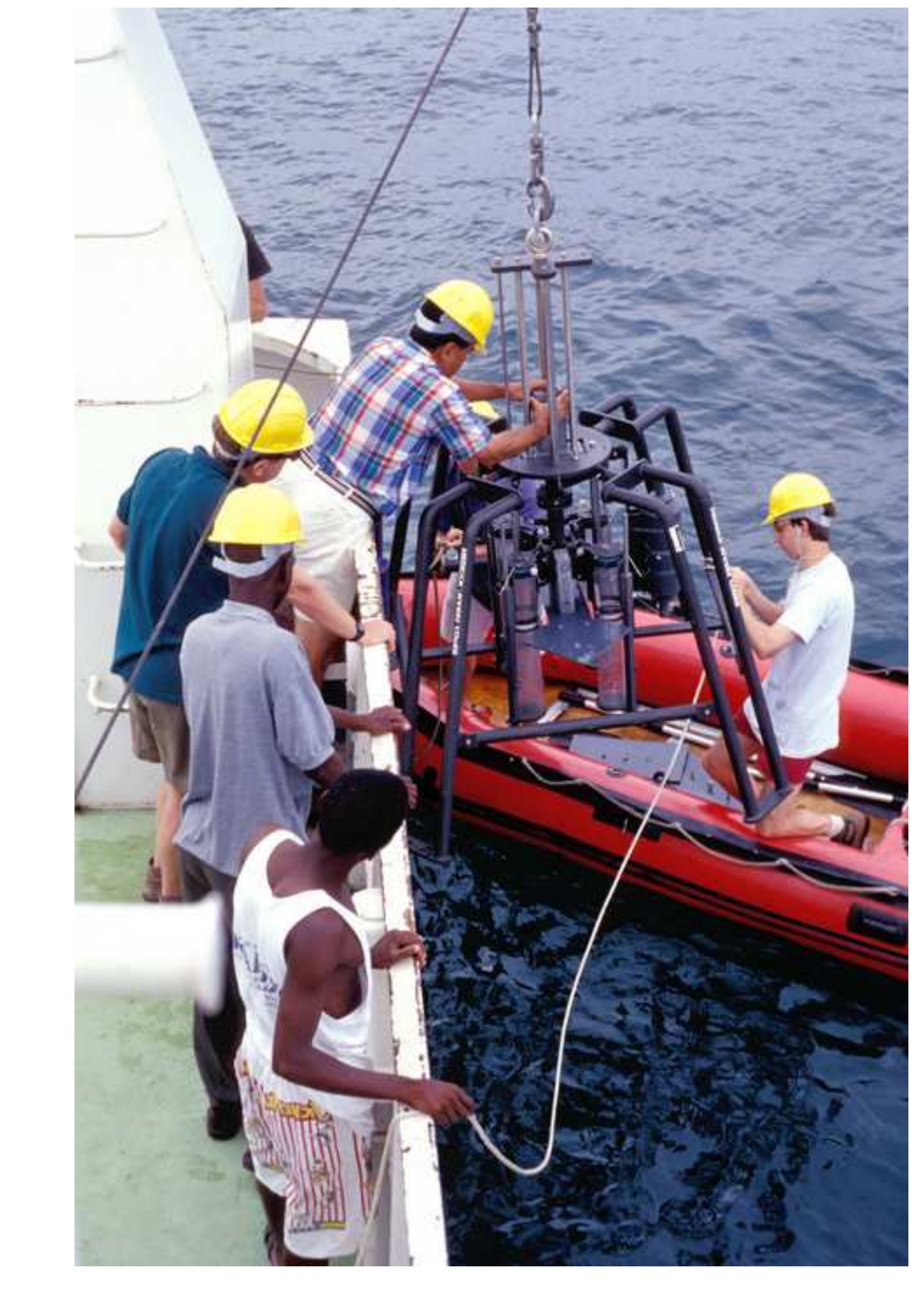

Graphical Abstract (for review)

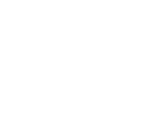

